\title{
PERLINDUNGAN HUKUM BAGI PEMBELI AKIBAT KELALAIAN PPAT DALAM PEMBUATAN AKTA JUAL BELI
}

\author{
LEGAL PROTECTION FOR BUYERS DUE TO NEGLIGENCE \\ CARRIED OUT BY PPAT
}

\author{
Fajriatul Tivani Haridhy \\ Program Studi Magister Kenotariatan \\ Fakultas Hukum, Universitas Syiah Kuala \\ E-mail : tivanyV@gmail.com \\ Ilyas Ismail \\ Fakultas Hukum Universitas Syiah Kuala \\ E-mail: ilyas.ismail@unsyiah.ac.id

\section{Darmawan} \\ Fakultas Hukum Universitas Syiah Kuala \\ E-mail: darmawan@unsyiah.ac.id
}

\begin{abstract}
PPAT is a general officer who is authorized to make a sale and purchase deed should duly have a prudential principle in carrying out its duties because the deed issued by the PPAT is used as legal certainty for the parties, but it is often found negligence carried out by the PPAT resulting in losses. In any form of error, if it is proven, PPAT has the obligation to account for the deed made by the PPAT. This research was conducted to examine the PPAT's responsibility for losses suffered by buyers. This study uses the normative legal research method using a legislative approach, conceptual approach, and case approach. The results of this study indicate that the PPAT accountability legally against the loss suffered by the buyer is the PPAT is obliged to replace any losses experienced by the buyer in which compensation is in the form of reimbursement, based on the results of the decision of the Banda Aceh District Court Number 7 / Pdt.G / 2016 / PN.Bna and Number 21 / Pdt.G / 2013 / PN-BNA.
\end{abstract}

\section{Keywords : deed of sale; annulling; PPAT}

\begin{abstract}
Abstrak
PPAT selaku pejabat publik yang mempunyai kewenangan untuk melakukan pembuatan akta jual beli sudah sepatutnya menerapkan prinsip kehati-hatian dalam menjalankan tugas sebab produk hukum yaitu akta otentik yang dikeluarkan PPAT dijadikan sebagai kepastian hukum bagi para pihak, namun sering dijumpai kelalaian yang dilakukan oleh PPAT mengakibatkan para pihak mengalami kerugian. Apabila PPAT terbukti melakukan kesalahan maka PPAT diwajibkan untuk bertanggung jawab atas akta tersebut. Penelitian ini dilakukan untuk mengkaji mengenai pertanggungjawaban oleh PPAT akibat pembeli mengalami kerugian. Metode yang digunakan yaitu metode yuridis normative dengan pendekatan undangundang, konsep, serta kasus. Hasil dari penelitian yaitu pertanggungjawaban PPAT terhadap kerugian yang diderita oleh pembeli akibat akta jual beli yang dibuat tidak berdasarkan aturan hukum adalah PPAT diwajibkan untuk mengganti atas kerugian
\end{abstract}


yang diderita pembeli yang mana penggantian itu berupa penggantian biaya, berdasarkan hasil penetapan putusan PN Banda Aceh Nomor 7/Pdt.G/2016/PN.Bna dan Nomor 21/ Pdt.G/2013/PN-BNA, serta akta, surat-surat dan sertikat sepanjang berhubungan dengan objek tersebut dinyatakan tidak mempunyai kekuatan hukum.

\section{Kata Kunci: Akta jual beli; Pembatalan; PPAT;}

\section{PENDAHULUAN}

Dalam Peraturan Pemerintah Nomor 24 Tahun 2016 tentang Perubahan atas Peraturan Pemerintah Nomor 37 Tahun 1998 tentang Peraturan Jabatan Pejabat Pembuat Akta Tanah mengatur mengenai kewenangan seorang PPAT yang menyatakan Pejabat Pembuat Akta Tanah adalah pejabat publik yang mempunyai wewenang yang diberikan oleh Negara untuk melakukan pembuatan akta yang berkaitan dengan peristiwa hukum terutama dalm hal hak atas tanah.

PPAT sebagai pejabat publik dimana Negara memberikan wewenang kepadanya untuk mencatat mengenai terjadinya suatu kesepakatan antara dua orang atau lebih dalam suatu akta yang melihat secara langsung kesepakatan antara para pihak yang mengikatkan dirinya. Yang kemudian oleh PPAT menuangkan janji yang telah dibuat yaitu kesepakatan antara para pihak di dalam suatu akta, kesepakatan tersebut merupakan kehendak tulus oleh pihak-pihak yang terlibat dalam kesepakatan tersebut. ${ }^{1}$ Pasal 3 huruf $\mathrm{f}$ dan $\mathrm{g}$ yang tercantum dalam Kode Etik IPPAT menentukan bahwa PPAT wajib bertindak dengan penuh rasa tanggungjawab, mandiri, bersifat transparan, dengan penuh hati-hati, bersikap adil serta dapat merahasiakan informasi pihak yang terlibat dalam peristiwa hukum serta PPAT dapat memberikan sosialisasi mengenai hukum terhadap masyarakat yang membutuhkan jasanya. ${ }^{2}$

PPAT selaku pejabat publik dalam melaksanakan tugas dapat menerapkan prinsip kehati-hatian, harus peka tanggap dan mempunyai ketajaman berpikir serta dapat memberikan masukan hukum mengenai perbuatan hukum maupun peristiwa sosial yang akan timbul, sehingga dengan begitu PPAT mempunyai keberanian dalam melakukan suatu tindakan dengan tepat. Keberanian dalam artian yaitu PPAT melaksanakan tugas merujuk pada peraturan hukum berlaku serta sedapat mungkin menolak membuat akta jual beli dimana tidak berdasarkan pada ketentuan yang telah diatur. ${ }^{3}$

Akta jual beli merupakan akta otentik yang dibuat dihadapan PPAT sebagai peralihan hak atas tanah dan bangunan. Dalam melakukan jual beli tanah para pihak harus membuat akta jual beli yang dilakukan dihadapan PPAT sebagai syarat untuk melakukan jual beli tanah. PPAT selaku pejabat yang diberi wewenang oleh pemerintah dalam hal pembuatan akta jual beli tanah sudah sepatutnya harus memiliki prinsip kehati-hatian dalam menjalankan tugas karena akta jual beli yang dikeluarkan oleh PPAT dijadikan sebagai kepastian hukum bagi para pihak, namun sering dijumpai kelalaian yang dilakukan oleh PPAT mengakibatkan para pihak mengalami kerugian. Jika terbukti PPAT melakukan kesalahan baik karena kesalahan kelalaian maupun kesalahan dalam bentuk kesengajaan maka PPAT mempunyai kewajiban untuk bertanggungjawabab terhadap kesalahan dalam pembuatan akta jual beli tersebut.

Putusan Pengadilan Negeri Banda Aceh No.7/Pdt.G/2016/PN Bna- merupakan satu dari beberapa kasus yang terjadi, untuk kasus ini terjadi pada tahun 2004, yaitu

\footnotetext{
${ }^{1}$ Putrid, Perlindungan Hukum Terhadap Notaris: Indikator Tugas-Tugas Jabatan Notaris Yang Berimplikasi Perbuatan Pidana, PT. Softmedia, Jakarta, 2011, hlm. 7.

${ }^{2}$ Pasal 3 huruf $\mathrm{f}$ dan g, Kode Etik Ikatan Pejabat Pembuat Akta Tanah

${ }^{3}$ Wawan Setiawan, Sikap Profesionalisme Notaris Dalam Pembuatan Akta Otentik Dalam Media Notariat, Edisi Mei-Juni, 2004, hlm. 23.
} 
kasus mengenai akta jual beli yang mana antara kedua belah pihak telah secara resmi melakukan pengikatan jual beli tanah yang dibuat dan dihadiri oleh PPAT tersebut. Setelah pihak penjual menyerahkan tanah beserta rumah kepada pembeli kemudian pembeli menempati rumah tersebut hingga kini, namun pada tahun 2013 pihak pembeli didatangi oleh beberapa pegawai bank Bukopin yang menyatakan bahwa rumah tersebut sudah menjadi objek jaminan bank. Ternyata tanpa sepengetahuan pihak pembeli, tanah beserta rumah tersebut sudah dijual oleh pihak penjual kepada pihak ketiga yang dilakukan di hadapan notaris yang sama. Kemudian pihak ketiga melakukan pengambilan kredit di bank dengan mengagunkan objek tersebut. Dari uraian kasus di atas akibat kelalaian oleh PPAT mengakibatkan pihak pembeli sangat dirugikan baik secara materiil maupun inmateriil.

Kesalahan yang dilakukan oleh PPAT dan jika kesalahan tersebut terbukti yang kemudian menimbulkan kecacatan dalam akta jual beli sehingga mengakibatkan akta tersebut menjadi batal demi hukum, maka akan timbul kerugian yang dialami oleh para pihak. Dengan demikian, PPAT dapat diminta untuk bertanggungjawab atas dasar kesalahan yang telah ia lakukan pada saat pembuatan akta jual beli dan PPAT diwajibkan untuk memberi ganti kerugian dalam bentuk penggantian biaya, bunga kepada para pihak yang mengalami kerugian berdasarkan hasil putusan Pengadilan Negeri Banda Aceh Nomor 7/Pdt.G/2016/PN Bna.

Dalam Pasal 1365 KUHPerdata menentukan bahwa seseorang yang karena kesalahannya telah menimbulkan kerugian bagi orang lain maka diwajibkan kepada yang menimbulkan kesalahan untuk mengganti kerugian yang telah ia lakukan tersebut. Pada praktiknya permasalahan itu timbul akibat tidak adanya prinsip kehati-hatian dari seorang PPAT sehingga akta jual beli tersebut tidak mempunyai kekuatan hukum atau bahkan menjadi batal demi hukum. Peristiwa tersebut dapat terjadi dalam waktu yang bersamaan/dalam waktu dekat atau dapat terjadi pada beberapa tahun yang akan datang ketika minuta akta telah disimpan oleh protokol PPAT lain. ${ }^{4}$

Putusan PN Banda Aceh No. 21/Pdt.G/2013/PN-BNA. adalah contoh lain bahwa PPAT melakukan kelalaian yang terjadi pada tahun 2009 yang mana penggugat melakukan pengikatan jual beli pada tanggal 22 Mei 2009 dengan tergugat I yang dilakukan dihadapan notaris dengan objek sengketa berupa tanah dan bangunan toko seharga Rp. 630.000.000,00-. Sebelumnya tergugat I melakukan perjanjian membangun dan bagi hasil dengan tergugat II yang mana tergugat I sebagai pihak yang membangun toko di atas tanah milik tergugat II. Dalam isi perjanjian membangun dan bagi hasil antara tergugat I dan tergugat II dikatakan bahwa tergugat II sudah memberikan hak dan kuasanya kepada tergugat I untuk menjual, memindahtangankan, dan menyerahkan kepada siapa saja, maka perjanjian jual beli tanah oleh tergugat I dan penggugat merupakan perjanjian yang sah.

Namun tergugat II memberitahukan kepada penggugat bahwa objek sengketa tersebut sudah dijual oleh tergugat II kepada tergugat IV atas permintaan tergugat I yang mana akta jual beli tersebut dilakukan dihadapan PPAT (tergugat VI). Tergugat IV melakukan pengambilan kredit di Bank BPD Aceh (tergugat VII) dengan mengagunkan objek sengketa tersebut atas nama tergugat I. Kepala Kantor Pertanahan Kabupaten Aceh Besar (tergugat VIII) sudah membaliknama atas sertifikat Hak Milik kepada tergugat IV tanpa memastikan dan mengecek objek sengketa yang bersangkutan. Oleh sebab perbuatan melawan hukum yang telah dilakukan para tergugat sehingga mengakibatkan

${ }^{4}$ Kunni Afifah, Tanggungjawab dan Perlindungan Hukum Bagi Notaris Secara Perdata Terhadap Akta Yang Dibuatnya, Jurnal Magister Kenotariatan Fakultas Hukum Universitas islam Indonesia, Vol.2 No.1, 2017, hlm. 147-161. 
penggugat mengalami banyak kerugian, sebab ketika PPAT membuat akta jual beli tidak mengecek/melihat sertifikat asli serta surat pendukung dari perjanjian jual beli tersebut.

Jika PPAT melakukan kelalaian ketika membuat akta jual beli maka banyak pihak yang akan mengalami kerugian, terutama dalam hal ini pihak penggugat. Oleh sebab timbulnya kerugian tersebut maka para tergugat yang didalamnya termasuk PPAT sebagai turut tergugat diharuskan untuk bertanggungjawab atas kerugian yang telah ia timbulkan kepada penggugat, serta semua surat-surat yang dibuat oleh PPAT tersebut yang berhubungan dengan objek sengketa tidak mempunyai kekuatan hukum jika dilihat dari hasil putusan PN Banda Aceh No. 21/Pdt.G/2013/PN-BNA.

PPAT selaku pejabat publik yang diberikan kewengan oleh pemerintah untuk membuat akta yang berkaitan dengan tanah sudah seharusnya mampu dan cakap serta menguasai hal-hal yang berhubungan dengan bidang pertanahan sehingga akta yang dikeluarkan oleh PPAT nantinya tidak menimbulkan masalah hukum di masa mendatang, sebab akta yang dibuat oleh PPAT merupakan akta otentik yang bisa dijadikan sebagai alat bukti di persidangan.

Masalah hukum tersebut dapat timbul pada akta jual belibersertifikat yang diakibatkan adanya kesalahan ketika pembuatan akta jual beli atau bisa terjadi kesalahan dalam hal prosedur penandatanganan akta tersebut. Hingga kini sering ditemukan dilapangan bahwa PPAT dalam menjalankan jabatannya yaitu membuat akta jual beli tidak sesuai dengan prosedur ketentuan peraturan hukum yang berlaku, oleh karena itu pihakpihak yang berkepentingan sering mengalami kerugian. Berdasarkan uraian latar belakang di atas yang menjadi permasalahan dalam penulisan ini yaitu bagaimanakah pertanggungjawaban PPAT secara hukum terhadap kerugian yang diderita oleh pembeli?

Adapun beberapa peneltian juga mengangkat isu mengenai kelalaian notaris dapat dilihat dalam tulisan Didi Santoso pada tahun 2009 yang berjudul Tanggungjawab Notaris dalam Pembuatan Akta yang Memuat Dua Perbuatan Hukum (Analisis Putusan Mahkamah Agung Nomor 1440.K/Pdt/1996) ${ }^{5}$ dan Ida Nurkhasanah pada tahun 2015 yang berjudul Pertanggungjawaban Notaris terhadap Akta Otentik yang dibuat di hadapannya (Studi terhadap Notaris di Kota Semarang) ${ }^{6}$.

Metode yang digunakan dalam penelitian ini yaitu metode penelitian hukum normatif. Penelitian ini mengkaji bahan kepustakaan terdiri dari bahan hukum dan dilengkapi oleh bahan hukum sekunder yang menyangkut penelitian secara menyeluruh dimana objek kajiannya adalah buku-buku, peraturan hukum serta bahan pustaka, suatu peraturan perundang-Undangan yang tergolong dalam bahan hukum primer. Dalam penelitian ini pendekatan yang digunakan adalah pendekatan perundang-undangan, pendekatan konsep, dan pendekatan kasus. Pengumpulan bahan hukum dengan melakukan studi pustaka dan studi dokumen, serta analisis bahan hukum dalam penelitian yaitu menggunakan analisis kualitatif. Serta yang menjadi tujuan dari penulisan ini agar dapat dikaji dan dianalisis mengenai tanggungjawab PPAT terhadap pembuatan akta jual beli yang tidak sesuai dengan aturan hukum.

\section{PEMBAHASAN}

Istilah tanggungjawab dapat dibedakan dengan pertanggungjawaban. Menurut kamus bahasa Indonesia, arti pertanggungjawaban adalah (1) perbuatan bertanggungjawab,

\footnotetext{
${ }^{5}$ Didi Santoso, Tanggungjawab Notaris dalam Pembuatan Akta yang Memuat Dua Perbuatan Hukum (Analisis Putusan Mahkamah Agung Nomor 1440.K/Pdt/1996), Jurnal Hukum, Universitas Diponegoro, 2009, Semarang.

${ }^{6}$ Ida Nurkhasanah, Pertanggungjawaban Notaris terhadap Akta Otentik yang dibuat di hadapannya (Studi terhadap Notaris di Kota Semarang), Tesis, Fakultas Hukum Program Pascasarjana, Universitas Negeri Semarang, 2015, Semarang.
} 
(2) sesuatu yang dipertanggungjawabkan. Dengan demikian, pada tanggungjawab lebih ditekankan pada adanya suatu kewajiban untuk menanggung yang dapat dikenakan, sedangkanpertanggungjawaban padaadanya sesuatu yang harus dipertanggungjawabkan, akibat dari dilakukannya suatu perbuatan atau peran tertentu. Istilah tanggungjawab hukum adalah kewajiban menanggung suatu akibat menurut ketentuan hukum yang berlaku yaitu norma atau peraturan hukum yang mengatur tentang tanggungjawab. ${ }^{7}$

Purbacaraka berpendapat ia menyatakan tanggungjawab bermula atau lahir dari adanya penggunaan fasilitas dalam menerapkan kemampuan terhadap setiap individu agar dapat digunakannya hak serta dapat memenuhi kewajibannya. Lebih lanjut ditegaskan, setiap pelaksanaan kewajiban dan setiap penggunaan hak, baik yang dilakukan secara tidak memadai maupun yang dilakukan secara memadai pada dasarnya tetap harus disertai dengan pertanggungan jawab, demikian pula dengan pelaksanaan kekuasaan. Dari pengertian di atas maka pertanggungjawaban merupakan perilaku atau perbuatan untuk dapat menanggung segala resiko dan konsekuensi atas suatu perbuatan yang ditimbulkannya. ${ }^{8}$

\section{Tanggung Jawab PPAT Terhadap Pembatalan Akta Jual Beli}

Dilihat dari segi Perdata atas dasar adanya perbuatan melawan hukum maka terhadap PPAT dapat diminta untuk bertanggung jawab, meskipun PPAT hanya menuangkan kesepakatan atau keinginan dari para pihak dalam suatu akta maka tidak menutup kemungkinan bahwa PPAT tidak melakukan kesalahan. ${ }^{9}$ Mengenai teori tanggungjawab hukum, Hans Kelsen menjelaskan bahwa konsep kewajiban hukum (responsibility) merupakan konsep yang terkait dengan kewajiban tanggungjawab hukum (liability). Dapat dikatakan bahwa seseorang bertanggungjawab atas suatu perbuatan tertentu apabila orang tersebut diberikan sanksi dalam suatu perbuatan yang berlawanan. Biasanya sanksi yang dapat diberikan kepada pelaku merupakan atas dasar tindakannya sendiri yang menimbulkan kerugian bagi orang lain sehingga pelaku tersebut diwajibkan untuk bertanggungjawab. ${ }^{10}$

Dalam mempertanggungjawabkan perbuatannya PPAT dapat bertanggungjawab atas pidana, perdata maupun administatif sesuai dengan pelanggaran ataupun kelalainnya. Untuk menentukan pertanggung jawabanya tersebut ada beberapa tolak ukur yaitu harus adanya unsur - unsur yang tegas dalam undang - undang tetang perbuatan Notaris ataupun hal - hal yang dilarang dalam Pasal 4 Kode Etik Ikatan Pejabat Pembuat Akta Tanah (IPPAT).

PPAT dalam melakukan pembuatan akta jual beli harus memenuhi ketentuan peraturan yang berlaku. Apabila PPAT melanggar peraturan yang telah diatur dalam peraturan perundang-Undangan PPAT tersebut dapat dikenai sanksi/hukuman. PPAT dalam pembuatan akta jual beli diharuskan untuk menggunakan formulir sesuai dengan bentuk yang telah ditetapkan Permenag/KBPN Nomor 3 Tahun 1997 Pasal 96 ayat (2). Jika formulir tersebut tidak digunakan pada saat melakukan peralihan hak atas tanah maka akta tersebut tidak bisa di gunakan untuk dasar pendaftaran hal ini diatur dalam Pasal 96 ayat (3) Pemenag/KBPN Nomor 3 Tahun 1997. Pada saat sebelum pembuatan akta, PPAT wajib melakukan pemeriksaan di kantor pertanahan terkait

\footnotetext{
${ }^{7}$ Wahyu Sasongko, Ketentuan-Ketentuan Pokok Hukum Perlindungan Consumen”, Tesis, Fakultas Hukum Program Pascasarjana, Universitas Lampung, Lampung, 2007, hlm, 96.

${ }^{8}$ Ida Nurkhasanah, Op. Cit, hlm. 33.

${ }^{9}$ Yusnani, Analisis Hukum Terhadap Akta Otentik Yang Mengandung Keterangan Palsu (Studi Kasus Di Kota Medan), Tesis, Fakultas Hukum Program Pascasarjana, Universitas Sumatera Utara, Medan, 2007, hlm, 61.

${ }^{10}$ Hans Kelsen, Teori Hans Kelsen Tentang Hukum, Cet. II, dierjemahkan oleh Jimly Asshiddiqie dan M. Ali Safaat, Konstitusi Press, Jakarta, 2012, hlm. 56.
} 
pengecekan sertifikat beserta data yang ada di kantor pertanahan untuk lebih jelasnya hal ini tercantum dalam Pasal 39 ayat (1) PP No. 24 Tahun 1997, kemudian PPAT dapat memeriksa dan melihat dokumen dari para pihak tersebut beserta dengan identitas diri mereka, kewenangan dan kewajiban perpajakan termasuk PBB serta hal-hal terkait lain yang diperlukan dalam pembuatan akta.

Para pihak harus ikut serta dalam pembuatan akta jual beli yang dilakukan oleh PPAT serta harus dihadiri saksi yang mana saksi tersebut minimal berjumlah 2 (dua) orang saksi tersebut harus merupakan cakap hukum agar ia dapat bertindak sebagai saksi hal ini diatur pada Pasal 38 ayat (1) Peraturan Pemerintah No. 24 Tahun 1997, serta dengan memperhatikan ketentuan-ketentuan tersebut dalam Pasal 39 Peraturan Pemerintah No. 24 Tahun 1997 tentang Pendaftaran Tanah. Jika dalam menjalankan tugas PPAT tidak merujuk pada peraturan yang telah ditetapkan, maka PPAT akan dikenakan sanksi yang telah di atur dalam Pasal 62 PP No. 24 Tahun 1997 tentang Pendaftaran Tanah.

Akta jual beli merupakan akta otentik yang dibuat oleh PPAT sebagai peralihan hak atas tanah dan bangunan. Dalam melakukan jual beli tanah memerlukan syarat yaitu dengan membuat akta jual beli. Pejabat Pembuat Akta Tanah selaku pejabat publik yang diberikan kewenangan dalam membuat akta jual beli sudah sepatutnya menerapkan prinsip kehati-hatian ketika menjalankan jabatannya sebab akta jual beli yang dikeluarkan oleh PPAT dijadikan sebagai kepastian hukum bagi para pihak, namun sering dijumpai kelalaian yang dilakukan oleh PPAT mengakibatkan para pihak mengalami kerugian. Apabila kesalahan tersebut terbukti maka sudah menjadi kewajiban PPAT untuk bertanggungjawab atas akta jual beli yang menimbulkan kesalahan tersebut.

Berdasarkan Pasal 1365 KUHPerdata menyatakan bahwa tiap-tiap perbuatan yang oleh karena perbuatan tersebut menimbulkan kerugian bagi orang lain maka diwajibkan kepadanya untuk mengganti kerugian tersebut. Terdapat unsur-unsur dalam Pasal 1365 KUHPerdata yaitu adanya suatu perbuatan melawan hukum, perbuatan itu harus menimbulkan kerugian baik secara materiil maupun imateriil, perbuatan tersebut karena kesalahan, adanya hubungan kausal antara perbuatan dan kerugian. Kerugian tersebut akibat adanya perbuatan yang melanggar hukum. Bisa dikatakan antara dua hal tersebut adanya sebab akibat secara langsung, timbulnya kerugian akibat adanya kesalahan yang dilakukan oleh pelakunya, kesalahan itu bisa dalam bentuk kesalahan karena kesengajaan atau kesalahan karena kelalaian (kealpaan). ${ }^{11}$

Ganti kerugian yang disebabkan oleh perbuatan melawan hukum merupakan bentuk ganti kerugian yang harus dilakukan oleh orang yang menyebabkan timbulnya kesalahan kepada orang yang mengalami kerugian. Ganti kerugian tersebut terjadi disebabkan adanya kesalahan, bukan karena adanya perjanjian. Bentuk ganti kerugian yang diatur dalam hukum perdata terdiri dari dua jenis, sebagai berikut :

1. Ganti rugi umum adalah terhadap semua kasus yang disebabkan oleh perbuatan melanggar hukum yang bentuk ganti ruginya berupa penggantian biaya dan bunga maka berlaku ganti rugi jenis ini. Pasal 1243-Pasal 1252 KUHPerdata mengatur mengenai jenis ganti rugi umum.

2. Ganti rugi khusus timbul jika adanya kesepakatan tertentu. ${ }^{12}$

Bentuk ganti kerugian pada perbuatan melawan hukum berbeda dengan ganti kerugian yang disebabkan karena wanprestasi, serta adanya kemungkinan ganti rugi

\footnotetext{
${ }^{11}$ Muhammad Abdulkadir, Hukum Perdata Indonesia, PT. Citra Aditya Bakti, Bandung, 1993, hlm. 525.

${ }^{12}$ Rosa Agustina, Perbuatan Melawan Hukum, Fakultas Hukum Universitas Indonesia, Jakarta, 2003, hlm. 31.
} 
dalam bentuk lain selain jumlah uang. Dalam hal ganti rugi dalam bentuk lain Hoge Read menguraikan sebagai berikut:

Pelaku yang melakukan perbuatan melawan hukum dikenakan sanksi untuk mengganti kerugian dengan membayar sejumlah uang kepada pihak yang merasa dirugikan tersebut, namun jika pihak yang menerima kerugian tersebut memilih untuk menentukan bentuk ganti rugi dan oleh hakim menyetujui hal tersebut, maka pihak yang menimbulkan kerugian tersebut diwajibkan untuk mengganti kerugiannya sesuai dengan kerugian yang dialami pihak tersebut.

\section{Tanggungjawab Hukum PPAT Akibat Kerugian yang Diderita oleh Pembeli}

Berkaitan dengan PPAT diatur dalam perundang-Undangan bahwasannya jika PPAT terbukti melakukan suatu pelanggaran dalam melaksanakan jabatannya maka PPAT tersebut dikenai sanksi administratif saja tidak diatur mengenai adanya sanksi perdata atau pidana kepada PPAT tersebut. Oleh karena itu jika PPAT melakukan suatu pelanggaran yang memenuhi delik perdata maka dikenakan sanksi perdata yang diatur dalam KUHPerdata, begitu juga jika PPAT melakukan suatu pelanggaran yang memenuhi delik pidana maka terhadap PPAT tersebut dikenakan sanksi pidana yang diatur dalam KUHPidana. ${ }^{13}$ Dalam hal tanggungjawab PPAT atas kesengajaan, kealpaan atau kelalaian pada saat pembuatan akta otentik (jual beli) yang tidak sesuai dengan syarat materil dan formil, terhadap PPAT dijatuhi sanksi administrasi. Jika dilihat dalam Perka BPN 1/2006 jika PPAT melakukan penyimpangan syarat formil dan syarata materil maka hal itu termasuk dalam pelanggaran berat dan oleh kepala Badan Pertanahan Nasional Indonesia dapat memberikan sanksi pemberhentian secara tidak hormat dari jabatan terhadap PPAT yang bersangkutan, hal tersebut diatur dalam Pasal 62 PP No. 24 tahun 1997 tentang Pendafataran Tanah. Dengan demikian sanksi pemberhentian secara tidak hormat dari jabatan serta dikenakan denda berupa denda administratif merupakan sesuatu yang dapat dijadikan ancaman terhadap PPAT apabila akta yang dibuatnya tidak memenuhi syarat materil dan formil dari suatu tata cara pembuatan akta jual beli.

Dalam kasus jual beli tanah ini terjadi sebelum tsunami pada tanggal 28 Juni 2004, penggugat membeli tanah dan rumah dari tergugat 1 seharga Rp. 190.000.000,- (seratus Sembilan puluh juta rupiah) dengan pembayaran secara bertahap. Bahwa penggugat pada tanggal 14 Juni 2007 telah melunasi pembelian tanah dan bangunan tersebut di atas kepada tergugat 1 ditambah ditambah dengan biaya-biaya suratnya berjumlah sebesar Rp. 197.500.000,- (seratus sembilan puluh tujuh juta lima ratus ribu rupiah) namun pada tanggal 26 Agustus 2007 tergugat 1 meminta untuk penambahan biaya surat menyurat sebesar Rp. 10.000.000,00- (sepuluh juta rupiah) terhadap penggugat sehingga berjumlah Rp. 207.500.000,00- (dua ratus tujuh juta lima ratus ribu rupiah ) yang telah penggugat bayarkan kepada tergugat I.Tergugat I telah menyerahkan objek berperkara dalam keadaan belum siap $100 \%$ kepada penggugat, kemudian penggugat menyelesaikan sendiri dan merehab objek tersebut. Penggugat beberapa kali menjumpai tergugat I untuk meminta sertifikat atas objek tersebut kepada penggugat namun tergugat I tidak beritikad baik untuk menyerahkan sertifikat objek tersebut.Pada saat tergugat I menyerahkan objek tersebut kepada penggugat, penggugat kuasai secara terus menerus sampai saat ini. Sekitar bulan Juni 2013 penggugat didatangi oleh pegawai Bank Bukopin (tergugat III) menempelkan stiker Bank Bukopin yang menyatakan bahwa tanah

${ }^{13}$ I Gusti Bagus Yoga Prawira, Tanggungjawab PPAT terhadap Akta Jual Beli Tanah, Jurnal Magister Kenotariatan Universitas Mataram, Vol.4, No.1, 2016, hlm. 66-78. 
dan bangunan ini telah menjadi jaminan Bank Bukopin. Penggugat terkejut karena penggugat tidak pernah mengagunkan objek tersebut dan biaya-biaya yang penggugat bayar kepada tergugat I adalah biaya penggugat sendiri. Ternyata tanpa sepengetahuan penggugat, tergugat I telah menjual objek tersebut kepada tergugat II yang dilakukan dihadapan notaris (tergugat IV). Kemudian tergugat II melakukan peminjaman kredit di Bank Bukopin dengan mengagunkan objek tersebut. Pihak Kepala Badan Pertanahan Kota Banda Aceh juga telah mengeluarkan sertifikat atas objek tersebut atas nama tergugat II.

Dari hasil putusan Nomor 7/Pdt.G/2016/PN Bna. terbukti bahwa tergugat I, tergugat II, tergugat III, tergugat IV dan tergugat $\mathrm{V}$ telah melakukan perbuatan melawan hukum. Seharusnya (das sollen) tergugat I menyerahkan objek kepada tergugat II dan tergugat II menerima penyerahan objek tersebut dari tergugat I, tergugat III mengecek dan memastikan dengan sebenarnya objek agunannya jangan sampai objek tersebut merupakan hak milik orang lain. Tergugat IV dan tergugat $V$ mengecek dan memastikan dengan sebenarnya sebelum mengeluarkan akta-akta dan surat-surat lainnya termasuk sertifikat-sertifikat. Pada kenyataannya pihak bank tanpa mengecek dan memastikan kelapangan mengenai objek agunannya sudah menyetujui untuk dijadikan jaminan bank. Hal ini tentu sangat merugikan pihak penggugat karena selama ini pihak penggugat telah menempati objek tersebut sampai dengan saat ini. Notaris (tergugat IV) dan kepala Badan Pertanahan Kota Banda Aceh (tergugat V) tidak mengeluarkan akta-akta dan sertifikat sebelum memastikan dan mengecek mengenai objek tersebut apakah objek tersebut benar-benar bersih dari kepemilikan pihak lain.

Oleh karena adanya perbuatan melawan hukum yang dilakukan tergugat I, tergugat II, tergugat III, tergugat IV, tergugat V tersebut baik karena perbuatan, tindakan serta kelalaiannya telah nyata merugikan penggugat. Dari hasil putusan Nomor 7/Pdt.G/2016/ PN Bna. akta-akta, sertifikat dan surat yang dikeluarkan oleh PPAT terkait dengan objek sengketa adalah tidak sah dan tidak mempunyai kekuatan hukum. Oleh karena itu majelis Hakim menetapakan untuk menghukum para turut tergugat termasuk PPAT untuk melunasi biaya perkara sebesar Rp. 2.699.000,00- (dua juta enam ratus sembilan puluh sembilan ribu rupiah).

Kasus kedua, Putusan Pengadilan Negeri Banda Aceh Nomor 21/Pdt.G/2013/ PN-BNA. adalah contoh lain bahwa PPAT melakukan kelalaian yang terjadi pada tahun 2009 yang mana penggugat melakukan pengikatan jual beli pada tanggal 22 Mei 2009 dengan tergugat I yang dilakukan dihadapan PPAT dengan objek sengketa berupa tanah dan bangunan toko seharga Rp. 630.000.000,00-. Sebelumnya tergugat I melakukan perjanjian membangun dan bagi hasil dengan tergugat II yang mana tergugat I sebagai pihak yang membangun toko di atas tanah milik tergugat II. Dalam isi perjanjian membangun dan bagi hasil antara tergugat I dan tergugat II dikatakan bahwa tergugat II sudah memberikan hak dan kuasanya kepada tergugat I untuk menjual, memindahtangankan, dan menyerahkan kepada siapa saja, maka perjanjian jual beli antara tergugat I dan penggugat adalah sah.

Tergugat II memberitahukan kepada penggugat bahwa objek sengketa tersebut sudah dijual oleh tergugat II kepada tergugat IV atas permintaan tergugat I yang mana akta jual beli tersebut dibuatdihadapan PPAT (tergugat VI). Tergugat IV melakukan pengambilan kredit di Bank Aceh (tergugat VII) dengan mengagunkan objek sengketa tersebut atas nama tergugat I . Kepala Kantor Pertanahan Kabupaten Aceh Besar (tergugat VIII) sudah membaliknamakan sertifikat Hak Milik kepada tergugat IV seharusnya BPN dalam menajalankan tugas harus memastikan dan mengecek terlebih dahulu objek 
sengketa yang bersangkutan, kemudian jika hasilnya bersih bahwa objek tersebut belum mempunyai alas hak maka BPN baru dapat mengeluarkan sertifikat. Hal ini juga diharapkan dapat diterapkan oleh BPN sehingga nantinya dapat mengurangi resiko kerugian yang akan dihadapi oleh masyarakat.

Akibat dari perbuatan melawan hukum yang dilakukan oleh para tergugat menyebabkan penggugat mengalami banyak kerugian, karena pada saat pembuatan akta jual beli PPAT tidak melihat sertifikat asli dan surat-surat yang mendukungnya dari perjanjian jual beli tersebut. Jika PPAT kurang teliti pada saat membuat akta jual beli, akan banyak pihak yang akan dirugikan, terutama bagi pihak penggugat. Atas kerugian tersebut, maka para tergugat termasuk PPAT di dalamnya harus membayar ganti rugi kepada penggugat dan segala surat-surat yang diterbitkan oleh PPAT itu tidak mempunyai kekuatan hukum, berdasarkan keputusan Pengadilan Negeri Banda Aceh Nomor 21/Pdt.G/2013/PN-BNA.

Dilihat dari segi Perdata atas dasar adanya perbuatan melawan hukum maka terhadap PPAT dapat diminta untuk bertanggung jawab, meskipun PPAT hanya menuangkan kesepakatan atau keinginan dari para pihak dalam suatu akta maka tidak menutup kemungkinan bahwa PPAT tidak melakukan kesalahan. ${ }^{14}$ Dalam mempertanggungjawabkan perbuatannya PPAT dapat bertanggungjawab atas pidana, perdata maupun administatif sesuai dengan pelanggaran ataupun kelalainnya. Untuk menentukan pertanggung jawabanya tersebut ada beberapa tolak ukur yaitu harus adanya unsur - unsur yang tegas dalam undang - undang tetang perbuatan Notaris ataupun hal - hal yang dilarang dalam Pasal 4 Kode Etik Ikatan Pejabat Pembuat Akta Tanah (IPPAT).

Berdasarkan pembahasan di atas tanggungjawab PPAT mengenai kesenjangan, kealpaan atau kelalaian PPAT pada saat membuat akta jual beli yang tidak memenuhi syarat materil dan formil mengenai prosedur pembuatan akta jual beli, maka untuk itu pihak yang merasa dirugikan dapat menuntut ganti rugi tidak hanya sebatas sanksi administratif saja. Mengenai kesalahan yang dilakukan oleh PPAT, haruslah ditelaah terlebih dahulu apakah kesalahan tersebut timbul karena wanprestasi atau perbuatan melawan hukum. Wanprestasi timbul apabila salah satu pihak melanggar perjanjian yang telah dibuat, sedangkan perbuatan melawan hukum tidak perlu adanya suatu kesepakatan atau perjanjian cukup timbulnya suatu kerugian yang dialami oleh pihak lain maka perbuatan tersebut sudah dikatakan sebagai perbuatan melawan hukum. ${ }^{15}$ Berdasarkan pada pengertian tersebut, suatu akta otentik yang dikeluarkan oleh PPAT, oleh karena kesalahan atau kelalaiannya akta tersebut menjadi cacat hukum atau menjadi akta dibawah tangan maka kesalahan yang timbul oleh PPAT tesebut dapat dikatakan suatu perbuatan melanggar hukum, karena baik pihak PPAT ataupun para pihak yang termuat dalam akta tidak pernah membuat suatu perjanjian telebih dahulu.

Penulis berpendapatbahwa akibat kesalahan yang dilakukan oleh PPAT baik itu karena kesengajaan, kelalaian/ketidaktelitian, kekuranghati-hatian, maupun ketidakcermatan dalam melaksanakan tugas dan jabatannya khusunya dalam hal ini membuat akta jual beli sehingga mengakibatkan timbulnya kerugian terhadap para pihak maka PPAT harus bertanggungjawab, berdasarkan hasil putusan Pengadilan Negeri Banda Aceh hakim memutuskan untuk memberikan sanksi kepada PPAT yang bersangkutan berupa penggantian biaya atas kerugian yang diderita oleh pembeli untuk kasus yang pertama

\footnotetext{
${ }^{14}$ Yusnani, Analisis Hukum Terhadap Akta Otentik Yang Mengandung Keterangan Palsu (Studi Kasus Di Kota Medan), Tesis, Fakultas Hukum Program Pascasarjana, Universitas Sumatera Utara, Medan, 2007, hlm, 61.

${ }^{15}$ Rosa Agustina, Op.Cit, hlm. 87.
} 
sebesar Rp. 2.699.000,00- (dua juta enam ratus sembilan puluh sembilan ribu rupiah), dan kasus kedua sebesar. Rp. 5.651.000, 00- (lima juta enam ratus lima puluh satu ribu rupiah).

Berdasarkan keputusan Pengadilan Negeri Banda Aceh Nomor 7/Pdt.G/2016/PN Bna, dan putusan Pengadilan Negeri Banda Aceh Nomor 21/Pdt.G/2013/PN-BNA, menyatakan bahwa PPAT yang bersangkutan terbukti bersalah dalam pembuatan akta jual beli tersebut. Hakim Pengadilan Negeri Banda Aceh menetapkan bahwa perbuatan hukum yang dilakukan oleh para tergugat menjadi batal demi hukum dan segala aktaakta dan surat yang dikeluarkan oleh PPAT adalah tidak sah dan tidak mempunyai kekuatan hukum serta menghukum pihak BPN untuk membaliknamakan Sertifikat Hak Milik kepada penggugat sebagai pemilik yang sah. Terhadap PPAT yang terbukti melakukan kesalahan dalam pembuatan akta jual beli seharusnya dapat dikenakan sanksi Pasal 62 PP No. 24 Tahun 1997 dan Pasal 6 kode etik IPPAT namun dalam kenyataannya sanksi tersebut tidak diberikan terhadap PPAT yang bersangkutan tetapi hanya merujuk pada putusan pengadilan Negeri Banda Aceh.

\section{SIMPULAN}

Pertanggungjawaban PPAT terhadap kerugian yang diderita oleh pembeli akibat akta jual beli yang dibuat tidak berdasarkan aturan hukum adalah PPAT diwajibkan untuk mengganti atas kerugian yang diderita pembeli yang mana penggantian itu berupa penggantian biaya, berdasarkan hasil penetapan putusan pengadilan Negeri Banda Aceh Nomor 7/Pdt.G/2016/PN.Bna dan Nomor 21/Pdt.G/2013/PN-BNA, serta akta, surat-surat dan sertikat sepanjang berhubungan dengan objek tersebut dinyatakan tidak mempunyai kekuatan hukum.

PPAT yang telah melakukan kesalahan tersebut dapat diberikan sanksi/hukuman antara lain: dikenakan berupa sanksi denda administrasi hingga pemecatan secara tidak hormat dari jabatannya sebagaimana yang telah diatur dalam Pasal 62 PP No. 24 Tahun 1997 dan Pasal 10 PP No. 37 Tahun 1998 dan sanksi keperdataan yaitu akta yang dikeluarkan oleh PPAT tidak memeiliki kekuatan hukum dan untuk kasus yang dipaparkan di atas hakim pengadilan negeri Banda Aceh menyatakan akta jual beli yang dikeluarkan oleh PPAT menjadi batal demi hukum serta perbuatan melawan hukum yang telah dilakukan PPAT yang mana akibat kelalaiannya dalam membuat akta menyebabkan timbulnya kerugian yang dialami oleh para pihak maka PPAT bertanggungjawab untuk mengganti kerugian berupa penggantian biaya kepada pihak yang mengalami kerugian.

\section{DAFTAR PUSTAKA}

\section{Buku}

Abdulkadir Muhammad, (1993), Hukum Perdata Indonesia, PT. Citra Aditya Bakti, Bandung.

Hans Kelsen, (2012), Teori Hans Kelsen Tentang Hukum, Cet II, diterjemahkan oleh Jimly Asshiddiqie dan M. Ali Safaat, Konstitusi Press, Jakarta.

Lumban Tobing, 1996, Undang-Undang Jabatan Notaris, Erlangga, Jakarta.

Notodisoerjo, (1982), Hukum Notarial di Indonesia (Suatu Penjelasan), Rajawali Pers, Jakarta.

Putrid AR, (2011), Perlindungan Hukum Terhadap Notaris: Indikator Tugas-Tugas Jabatan Notaris Yang Berimplikasi Perbuatan Pidana, PT. Softmedia, Jakarta. 
Rachmat Setiawan, (1991), Tinjauan Elementer Perbuatan Melanggar Hukum, Cet I, Bina Cipta, Bandung.

Rosa Agustina, (2003), Perbuatan Melawan Hukum, Fakultas Hukum Universitas Indonesia, Jakarta.

Sjaifurrachman, (2011), Aspek Pertanggungjawaban Notaris dalam Pembuatan Akta, Mandar Maju, Bandung.

Toedjasaputro, Liliana, (1995), Etika Profesi Notaris Dan Profesi Hukum, Aneka Ilmu, Semarang.

\section{Jurnal dan karya ilmiah lain}

Wawan Setiawan, Sikap Profesionalisme Notaris Dalam Pembuatan Akta Otentik Dalam Media Notariat. Edisi Mei-Juni, 2004.

Kunni Afifah, (2017), Tanggungjawab Dan Perlindungan Hukum Bagi Notaris Secara Perdata Terhadap Akta Yang Dibuatnya, Jurnal Hukum Program Pascasarjana, Vol. 2, No.1, hal 147-161.

I Gusti Bagus Yoga Prawira, (2016), Tanggung Jawab PPAT terhadap Akta Jual Beli Tanah, Jurnal Hukum, Vol. 4, No. 1, hal 66-78.

Didi Santoso, (2009), Tanggungjawab Notaris dalam Pembuatan Akta yang Memuat Dua Perbuatan Hukum (Analisis Putusan Mahkamah Agung Nomor 1440.K/ Pdt/1996), Jurnal Hukum, Magister Kenotariatan, Universitas Diponegoro, Semarang.

Ida Nurkhasanah, (2015), Pertanggungjawaban Notaris terhadap Akta Otentik yang dibuat di hadapannya (Studi terhadap Notaris di Kota Semarang), Tesis, Fakultas Hukum Program Pacasarjana, Universitas Negeri Semarang, Semarang.

Wahyu Sasongko, (2007), Ketentuan-Ketentuan Pokok Hukum Perlindungan Consumen, Tesis, Fakultas Hukum Program Pascasarjana, Universitas Lampung, Lampung.

Yusnani, (2007), Analisis Hukum Terhadap Akta Otentik Yang Mengandung Keterangan Palsu (Studi Kasus Di Kota Medan), Tesis, Fakultas Hukum Program Pascasarjana, Universitas Sumatera Utara, Medan..

\section{Peraturan Perudang-undangan.}

Kitab Undang-undang Hukum Perdata

Undang-undang Nomor 2 Tahun 2014 tentang Perubahan Atas Undang-Undang Nomor 30 Tahun 2004 tentang Jabatan Notaris.

Undang-undang Nomor 4 Tahun 1996 tentang Hak Tanggungan.

Undang-undang Nomor 24 Tahun 2016 tentang Perubahan Atas Undang-Undang Nomor 37 Tahun 1998 tentang Peraturan Jabatan Pejabat Pembuat Akta Tanah.

Peraturan Pemerintah Nomor 24 Tahun 1997 tentang Pendaftaran Tanah.

Peraturan Menteri Agraria/Kepala BPN Nomor 1 Tahun 2006 tentang Ketentuan pelaksanaan peraturan pemerintah Nomor 37 Tahun 1998 tentang Peraturan PPAT. 